\title{
A Case Report on Hyponatremia: Leading Sign of Hypopituitarism [Secondary to Adrenal Insufficiency]
}

\author{
Dr. Poornima \\ Department of Pharmacology, \\ Sree Balaji Medical College \& Hospital, Chrompet -44 \\ Tamilnadu, India
}

\begin{abstract}
:
\section{Objective:}

Severe hyponatremia due to hypopituitarism and adrenal insufficiency can be life threatening and treatment with glucocorticoids is very effective once the diagnosis of the underlying disorder has been made. In our experience, the diagnosis of hypopituitarism in hyponatremic patients is often overlooked.

\section{$>$ Background:}

We report the case of a 54 year old female admitted to our hospital in an obtunded state with altered sensorium. We found that a severe hyponatremia was the cause of patient condition. Previously she was diagnosed with recurrent episodes of hyponatremia leading to encephalopathy. The diagnosis of hypopituitarism is often overlooked in hyponatremic patients. Hyponatremia should always be ruled out for endocrinological causes.
\end{abstract}

\section{Conclusion:}

Our study concludes that hyponatremia is due to hypopituitarism that is secondary to adrenal insufficiency leading to encephalopathy.

Keywords:- Hyponatremia; postpartum hypopituitarism; secondary to adrenal insufficiency; metabolic encephalopathy.

\section{INTRODUCTION}

Hyponatremia is the common electrolyte disorder with serum sodium level $<135 \mathrm{nmol} / \mathrm{L}$ seen in $1 \%$ of the general population, in which upto $30 \%$ of all patients treated in intensive care units.[1-3] In most cases, hyponatremia is the leading laboratory sign of hypopituitarism. Hypopituitarism is a rare condition that is often misdiagnosed and in elderly it is an under-investigated endocrine disorder, since its clinical features are unspecific

\author{
Dr. Arul Amutha Elizabeth \\ Proffessor \& Head of the Department of Pharmacology \\ Sree Balaji Medical College \& Hospital, Chrompet- 44, \\ Tamilnadu, India
}

and more often attributed to aging itself and related comorbidities[4-5]. The main cause of hyponatremia in this condition seems to be a failure of endogenous cortisol . [6]

In our case study, we describe the elderly woman whose clinical history of recurrent episodes of hyponatremia was overlooked and underlying hypopituitarism remained undiagnosed. Our study aim to support that, severe hyponatremia due to adrenal insufficiency can be rapidly corrected by hydrocortisone substitution [7] and also aim to support an hormonal assay in the initial diagnostic workup of hyponatremia to reduce the mortality rate in patients of hypopituitarism.

\section{CASE REPORT}

A 54 year old female normotensive, non diabetic admitted in an obtunded state with history of vomiting, fatigability, altered sensorium rapidly worsening over past 2 days. She had recurrent admissions for similar complaints in the past diagnosed with recurrent hyponatremia leading to encephalopathy.

She had significant obstretric history - after uneventful third delivery she notices failure of lactation , oligomennorhea and premature menopause at age of 35.On examination, she was hemodynamically stable with pulse rate $90 / \mathrm{min}$, respiratory rate $16 / \mathrm{min}$, body temperature 98.3F and blood pressure 120/80mmhg .

On Investigations, serum electrolytes revealed hyponatremia. Viral markers were negative. Evaluation of hyponatremia revealed euvolemic hyponatremia with low serum osmolarity. Urine osmolarity $>100 \mathrm{mosmol} / \mathrm{kg}$ and urine spot sodium $>20 \mathrm{meq} / \mathrm{l}$. Other parameters like CBC, Peripheral smear, RFT, RBS, LFT ,TFT, ECG, Chest x-ray , USG abdomen and CT brain were normal.

In order to rule out endocrinological causes, we proceeded with hormone study,[Table:1] 
ISSN No:-2456-2165

\begin{tabular}{|c|c|c|}
\hline Hormone & TEST value & Reference value \\
\hline CORTISOL(5AM) & $2.8 \mathrm{mcg} / \mathrm{dl}$ & $6.02-18 \mathrm{mcg} / \mathrm{dl}$ \\
\hline ALDOSTERONE & $76.28 \mathrm{pg} / \mathrm{ml}$ & $60-300 \mathrm{pg} / \mathrm{ml}$ \\
\hline GROWTH HORMONE & $0.55 \mathrm{ng} / \mathrm{ml}$ & $0.05-8 \mathrm{ng} / \mathrm{ml}$ \\
\hline TSH & $2.22 \mathrm{mlU} / \mathrm{ml}$ & $0.45-4.5 \mathrm{mIU} / \mathrm{ml}$ \\
\hline АСТн & $22.30 \mathrm{pg} / \mathrm{ml}$ & $10.46 \mathrm{pg} / \mathrm{ml}$ \\
\hline PROLACTIN & $1.74 \mathrm{ng} / \mathrm{ml}$ & $5.18-26.53 \mathrm{ng} / \mathrm{ml}$ \\
\hline FSH & $3.87 \mathrm{mIU} / \mathrm{ml}$ & $\begin{array}{lcc}\text { Follicular phase }-1.4-9.9 & \mathrm{mlU} / \mathrm{ml} \\
\text { Mid cycle- } & 0.2-17.2 & \mathrm{mlU} / \mathrm{ml} \\
\text { Luteal phase- } & 1.1-9.2 & \mathrm{mIU} / \mathrm{ml} \\
\text { Post menopausal-19.3-100.6 } \mathrm{mlU} / \mathrm{ml}\end{array}$ \\
\hline LH & $1.39 \mathrm{mlU} / \mathrm{ml}$ & \begin{tabular}{lrr} 
Follicular phase & \multicolumn{1}{c}{$1.7-15$} & $\mathrm{mIU} / \mathrm{ml}$ \\
Mid cycle- & $21.9-56.6$ & $\mathrm{mIU} / \mathrm{ml}$ \\
Luteal phase- & $0.6-16.3$ & $\mathrm{mIU} / \mathrm{ml}$ \\
Post menopausal-14.2-52.3 & $\mathrm{mIU} / \mathrm{ml}$
\end{tabular} \\
\hline
\end{tabular}

Fig 1

Serum cortisol very low

CT abdomen showed normal adrenal glands

$>$ Hormonal panel revealed reduced FSH, LH and Prolactin.

$>$ ACTH, Aldosterone, TSH and GH were normal.

$>$ Pituitary cell autoantibodies were positive.

MRI revealed Empty sella with compression of anterior pituitary.

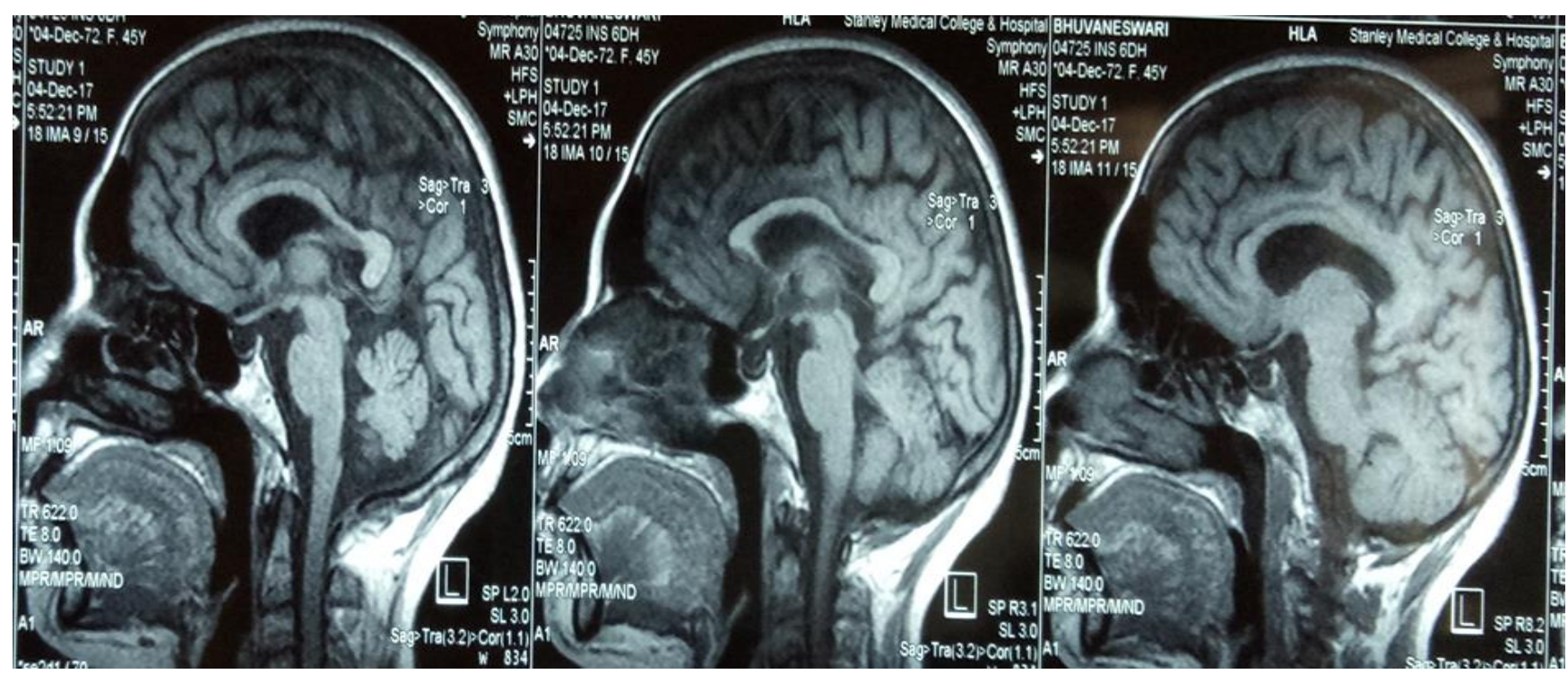

Fig 2

Therapeutically, we started correcting hyponatremia from the day of admission with free water restriction and 3\% hypertonic saline. After the hormonal study, on day 8 of admission patient was treated with hydrocortisone which led to a return of serum sodium into normal range in 3-5 days. A written informed consent to publish a entire patient's data has been obtained. 


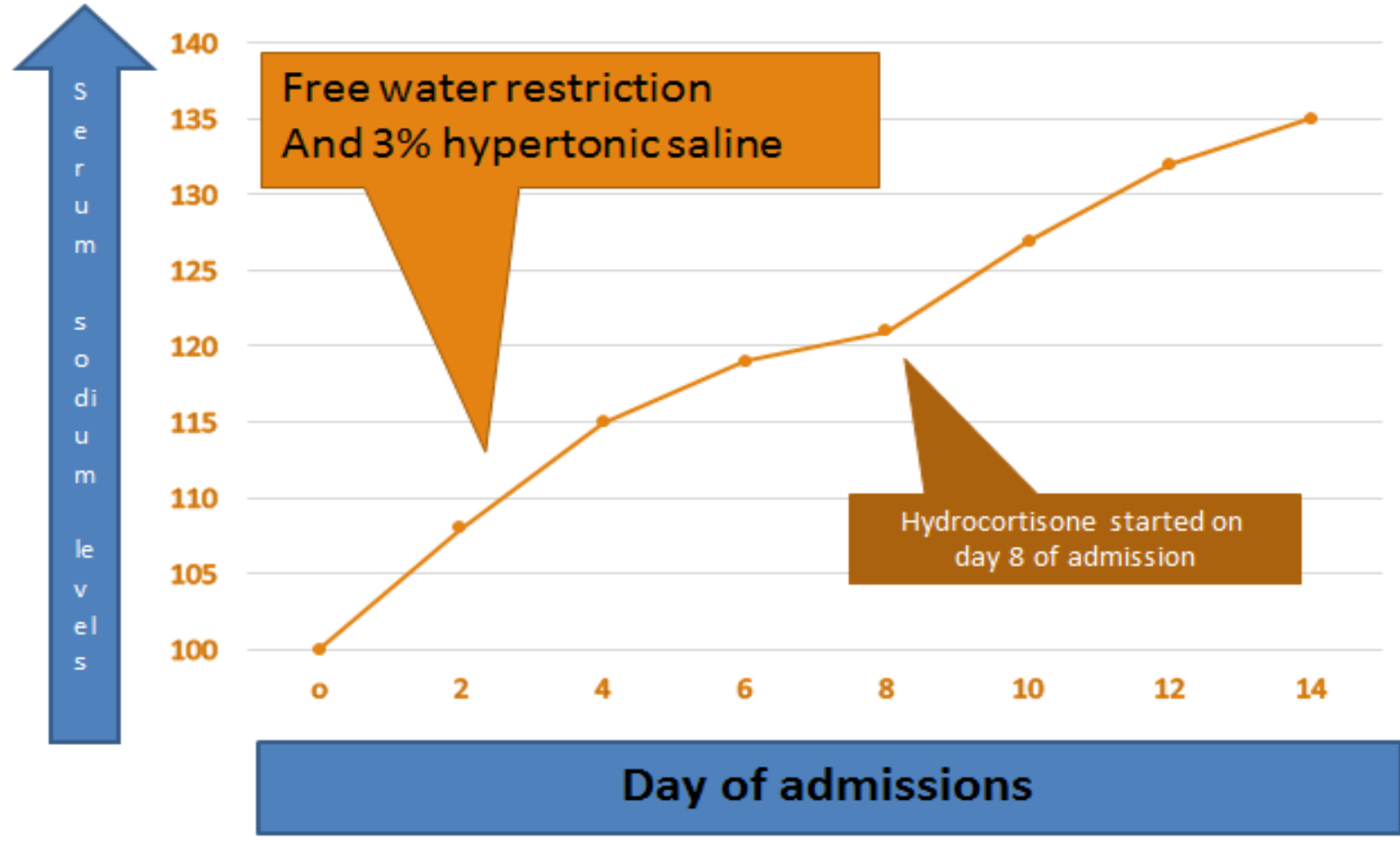

Fig 3

\section{DISCUSSION}

Hyponatremia, defined as a serum sodium concentration $<136 \mathrm{meq} / \mathrm{L}$, is a frequent electrolyte disorder in the general population[1-3] and in hospitalized patients. Mild cases are usually asymptomatic, but severe hyponatremia may cause a high mortality [8] depending its underlying disorder. Detailed history, physical and laboratory examination often provide useful ideas for identifying the underlying cause.[9]

Hypopituitarism is a relatively rare disorder; its incidence and prevalence being 4.2 per 100,000 per year and 45.5 per 100,000 respectively[11] .Unfortunately, most of the physicians consider hyponatremia as abnormal consequence of aging in which hypopituitarism is overlooked in such cases.[10]

Hyponatremia has several underlying causes such as cortisol insufficiency, SIADH, chronic intestinal nephritis , salt losing nephropathies[14], cerebral salt wasting, diuretic excess/other drugs. Thiazide diuretics and the syndrome of inappropriate $\mathrm{ADH}$ secretion (SIADH) are the commonest causes of hyponatremia encountered in clinical practice[12,13]. It shouldn't be misdiagnosed as SIADH.

Our case report is focused on hypopituitarism presenting as recurrent episodes of hyponatremia leading to metabolic encephalopathy, being the most common electrolyte disorder in our clinical practice. In addition she had lactation failure with premature menopause.

Patient was hemodynamically stable with chronic symptomatic euvolemic hyponatremia with low serum osmolality. Then we have proceeded with hormonal study and radiological assessments which revealed Empty sella with compression of anterior pituitary in MRI and decreased levels of cortisol and hormonal FSH, LH and Prolactin levels in blood parameters. On further assessment , pituitary cell autoantibodies were also positive in this patient.

Treatment has been started since the day of admission with free water restriction and 3\% hypertonic saline. Later on $8^{\text {th }}$ day of admission after all the assessment results were obtained, patient was started on injection. Hydrocortisone and compared with the patient's serum sodium levels which shows the significance that sodium level is maintained within normal range few days after the start of hydrocortisone. Quick and evident improvement of clinical condition occurred after correction of both hyponatremia and its underlying hormonal deficit. Hyponatremia should not be overlooked, as it could be an early sign of hypopituitarism.

In the present study, Hyponatremia can be the presenting feature of hypopituitarism . In addition patient had lactation failure with premature menopause which is suggestive of postpartum hypopituitarism could have been due to autoimmune hypophysitis. Therefore, this is a case of atypical presentation of secondary adrenal insufficiency leading to metabolic encephalopathy.

As there is excess mortality associated with hypopituitarism, hormone assays should be included in the initial diagnostic work-up of hyponatremia. Appropriate and timely therapy of Hyponatremia and hypopituitarism is key to reduce the related high mortality rate. 


\section{CONCLUSION}

In the present study, Hyponatremia can be the presenting feature of hypopituitarism. In addition patient had lactation failure with premature menopause which is suggestive of postpartum hypopituitarism. Therefore, this is a case of atypical presentation of secondary adrenal insufficiency leading to metabolic encephalopathy.

\section{REFERENCES}

[1]. Spasovski G, Vanholder R, Allolio B, et al. Clinical practice guideline on diagnosis and treatment of hyponatraemia. Eur J Endocrinol. 2014;170:G1-G47. [pubmed] [Google Scholar]

[2]. Drake -Holland AJ,Noble MI.The hyponatremia epidemic :a frontier too far?Front cardiovasc Med 2016;3:35[ecollection].

[3]. Giordano M,Ciarambino T, Castellino P, Malatino L,Di Somma S,Biolo G, et al. Diseases associated with electrolyte imbalance in the ED : age related differences. Am J Emerg Med 2016;34:1923e6.

[4]. Catalano A, Basile G, Lasco A. Hypocalcemia: a sometimes overlooked cause of Heart failure in the elderly. Aging Clin Exp Res 2012;2012(24):400e3.

[5]. Higham CE, Johannsson G, Shalet SM. Hypopituitarism Lancet 2016;388: 2403e15.

[6]. Erkut ZA, Pool C \& Swaab DF. Glucocorticoids suppress Corticotropin-releasing hormone and vasopressin expression in Human hypothalamic neurons. Journal

[7]. Bethune JE \& Nelson DH. Hyponatremia in hypopituitarism. New England Journal of Medicine 1965272 771-776.

[8]. Anderson RJ, Chung HM, Kluge R \& Schrier RW. Hyponatremia: A prospective analysis of its epidemiology and the pathogenetic Role of vasopressin. Annals of Internal Medicine 1985102 $164-168$.

[9]. Wakil A, Ng JM, Atkin SL. Investigating hyponatraemia. BMJ 2011; 342.D1118.

[10]. Curt_o L, Trimarchi F. Hypopituitarism in the elderly: a narrative review on Clinical management of hypothalamic-pituitary-gonadal, hypothalamicpituitary- Thyroid and hypothalamic-pituitary-adrenal axes dysfunction.J Endocrinol Invest 2016;39:1115e24.

[11]. Higham CE, Johannsson G, Shalet SM. Hypopituitarism Lancet 2016;388: 2403e15.

[12]. Wald R, Jaber BL, Price LL, Upadhyay A, Madias NE. Impact of hospitalassociated Hyponatremia on selected outcomes. Arch Intern Med 2010;170:294e302.

[13]. Adrogue HJ, Madias NE. Hyponatremia. N Engl J Med 2000;342:1581e9. Dreakhshan A, Hekmat VR.

[14]. Acute glomerulonephritis in Southern Iran. Iran J Pediatr. 2008; 18:143-148. [Google Scholar] 